\title{
OS TRATADOS INTERNACIONAIS DE DIREITO TRIBUTÁRIO NO DIREITO BRASILEIRO
}

Milena Zampieri Sellmann

Doutora, Mestre e especialista em Direito pela PUC-SP. Professora nos cursos de graduação e pós-graduação (especialização e mestrado) do Unisal de Lorena. Professora do Damásio Educacional e da Faculdade de Direito Damásio de Jesus. Advogada.

\section{Resumo}

Os tratados internacionais são a principal fonte de obrigações no âmbito internacional e geram reflexos na ordem interna. Têm grande atuação na seara tributária porque evitam a dupla tributação e diminuem encargos tributários no comércio internacional. São fontes formais do direito tributário, o que o legislador reconhece expressamente no artigo 96 do Código Tributário Nacional ao definir a expressão "legislação tributária". O artigo 98 do mesmo Código determina a supremacia do tratado internacional sobre a legislação interna. Ao contrário do previsto, as convenções internacionais tributárias não revogam, nem modificam a legislação interna, apenas limitam a eficácia da lei interna com eles incompatível, tendo hierarquia supralegal, porém infraconstitucional. Estão acima da legislação interna, seja anterior ou posterior, e estão abaixo da Constituição Federal, de modo que, os tratados com ela incompatíveis não deverão ser referendados pelo Congresso Nacional e, caso sejam, serão passíveis de declaração de inconstitucionalidade pelo o Supremo Tribunal Federal. É caso de denúncia da avença internacional a inconstitucionalidade superveniente a sua celebração.

\section{Palavras-chave}

Tratado internacional de Direito Tributário; Hierarquia supralegal; Direito brasileiro.

\section{Abstract}

International agreements are the primary source of obligations internationally, which generate reflections in national law. They have been extremely used in tax harvest because they avoid double taxation and reduce tax burden in international trade. They are formal sources of tax law, which the legislature is expressly recognized in Article 96 of the National Tax Code to set the "tax legislation" expression. Article 98 of the Code determines the supremacy of international tax agreements over national law. Against the 
odds, international tax agreements do not revoke or modify the national legislation, just limit the effectiveness of national law incompatible with them, with supra-legal hierarchy and infra-constitution. They are above national law, either after or before it is created, and are below the Federal Constitution, so agreements incompatible with it should not be approved by Congress and, if so, they will be subject to declaration of unconstitutionality by the Supreme Court. It is a reporting case the international agreement's unconstitutionality after it is celebrated.

\section{Key words}

International tax agreement; Supra-legal hierarchy. Brazilian law.

\section{Introdução}

Em decorrência do crescente positivismo no âmbito internacional, os tratados constituem atualmente a principal fonte de obrigaçóes entre Estados. Em matéria tributária, as convenções internacionais adquiriram especial relevo no comércio internacional na medida em que evitam dupla tributação e reduzem a carga tributária.

Para analisar os reflexos para o direito interno em decorrência da celebraçáo de uma convenção entre Estados serão apresentados os principais aspectos dos tratados internacionais em relação ao direito brasileiro, em especial, dos tratados de direito tributário e sua posição hierárquica na legislação interna. Tratar-se-á do conceito, do processo de formação, das teorias monista e dualista, as quais referem-se a incorporação das normas internacionais no direito pátrio.

Após aplicar-se-ão tais conceitos especificamente aos tratados de direito tributário, dando-se ênfase para a análise dos tratados internacionais como fonte do direito tributário, dos dispositivos do Código Tributário Nacional pertinente à matéria, e da hierarquia das convençóes internacionais de direito tributário na ordem interna.

Ao final, tecer-se-á algumas considerações conclusivas, esperando-se, sem pretensão de exaurir as questóes ventiladas, responder à problemática do presente trabalho.

\section{Conceito de Tratados Internacionais}

Em razão do crescente positivismo jurídico, particularmente no âmbito internacional, os tratados internacionais tornaram-se a principal fonte de obrigaçóes do direito internacional. ${ }^{1}$

1 Valério de Oliveira Mazzuoli (Tratados internacionais, p. 13) leciona que: "Os tratados são, incontestavelmente, a principal fonte do direito internacional, não apenas em relação à segurança e estabilidade que 
Como forma de codificação do direito internacional consuetudinário e para disciplinar e regular o processo de formação dos tratados internacionais, servindo como a Lei dos Tratados, foi elaborada a Convenção de Viena sobre o Direito dos Tratados (CVDT), cujo texto foi ultimado em 23 de maio de 1969, a qual tratou apenas das avenças internacionais entre Estados, deixando de lado aquelas das quais participam organismos internacionais. $^{2}$

$\mathrm{O}$ artigo $2^{\circ}$, no I, alínea "a”, da Convenção de Viena define o termo tratado como um acordo internacional entre Estados, por escrito, regido pelo direito internacional, inserido num único instrumento ou em dois ou mais conexos, qualquer que seja a sua denominação particular.

A doutrina oferece vasta definição do termo. José Francisco Rezek define tratado como "todo acordo formal concluído entre sujeitos de direito internacional público, e destinado a produzir efeitos jurídicos" ${ }^{3}$. Flávia Piovesan leciona que "os tratados são acordos internacionais celebrados entre sujeitos de Direito Internacional, sendo regulados pelo regime jurídico do Direito Internacional” . Luis Ivani de Amorim Araújo conceitua

trazem nas relaçóes internacionais, mas também porque tornam o direito das gentes mais representativo e autêntico, na medida em que se consubstanciam na vontade livre e conjugada das naçôes, sem a qual não subsistiriam". O artigo 38 do Estatuto da Corte Internacional de Justiça enumera as fontes do direito internacional como sendo: a) as convenções internacionais; b) o costume internacional; c) os princípios gerais de direito; e d) as decisóes judiciais e a doutrina. Sobre a importância do costume internacional como fonte do direito internacional, comenta Hee Moon Jo (Introdução ao direito internacional, p. 78): "A fonte mais importante do direito internacional foi, durante séculos, o costume internacional evoluído da prática dos Estados. O recente movimento para a codificação do direito internacional e a conclusão de tratados multilaterais em várias áreas, como no direito do mar, no direito de guerra e nas relaçōes diplomáticas e consulares é a concretização dos costumes internacionais, o qual forma as normas internacionais universalmente aceitas na sociedade internacional. O costume internacional ainda predomina em várias áreas do direito internacional, e está sendo constantemente criado. Entretanto, a sistematização da sociedade internacional faz com que cada vez mais a importância do costume internacional perca a sua tradicional importância”.

2 A Convençáo de Viena sobre o Direito dos Tratados somente entrou em vigor em 27 de janeiro de 1980, quando, consoante art. 84, chegou ao quorum mínimo de trinta e cinco Estados-partes. Conta com a ratificação de 101 Estados. O Brasil assinou a Convenção em 1969, o Executivo encaminhou ao Legislativo, em abril de 1992, o texto da Convençẫo para exame e aprovação, mas ainda não houve a ratificação (http://pt.wikipedia.org).

3 Direito internacional público: curso elementar, p. 14.

4 Temas de direitos humanos, p. 66. Leciona ainda Flávia Piovesan (Ibid, p. 67): "A primeira regra a ser fixada é a de que os tratados internacionais só se aplicam aos Estados-partes, ou seja, aos Estados que expressamente consentiram com sua adoção. Os tratados náo podem criar obrigaçóes aos Estados que com eles náo consentiram, ao menos que preceitos constantes do tratado tenham sido incorporados pelo costume internacional. Como dispóe a Convenção de Viena: "Todo tratado em vigor é obrigatório em relação às partes e deve ser observado por elas de boa fé”. Complementa o art. 27 da Convenção: “Uma parte não pode invocar disposiçóes de seu direito interno como justificativa para o náo-cumprimento do tratado". Logo, os tratados são, por excelência, expressão de consenso. Apenas pela via do consenso podem os tratados criar obrigaçóes legais, uma vez que Estados soberanos, ao aceitá-los, comprometemse a respeitá-los. A exigência do consenso é prevista pelo art. 52 da Convenção de Viena, quando dispôe 
tratado como “... um ato jurídico segundo o qual os Estados Soberanos e Organizaçóes Internacionais que obtiveram personalidade por acordo entre diversos Estados, criam, modificam ou extinguem uma relação de direito existente entre eles" ${ }^{\text {. }}$.

Sobre a terminologia a ser empregada para as avenças internacionais questiona José Francisco Rezek:

Há razão científica porque o tratado constitutivo da OIT se chama constituição, enquanto, à fundação de tantas outras organizaçóes internacionais, se deu preferência ao vocábulo carta? Termos como acordo, ajuste, ou convênio, designam sempre um tratado de importância medíocre? $\mathrm{O}$ protocolo é necessariamente um tratado acessório? A realidade do direito convencional contemporâneo rende algum tributo às velhas tentativas doutrinárias de vincular, a cada termo variante de tratado, certa modalidade bem caracterizada de compromissos internacional? A esta última questão a resposta é firmemente negativa. O que a realidade mostra é o uso livre, indiscriminado, e muitas vezes ilógico, dos termos variantes daquele que a comunidade universitária, em toda parte - não houvesse boa razão para isso -, vem utilizando como termo-padrão. ${ }^{6}$

Desta forma, os acordos internacionais podem ser denominados por "tratados" como também por outras designações, as mais comuns são: Convençôes, Acordos, Protocolos, Cartas, Estatutos, Convênios, Pactos, Constituiçóes, dentre outras. Alguns termos são usados para configurar solenidade (Pacto ou Carta) ou a natureza suplementar do acordo (protocolo $)^{7}$, mas a denominação a ser utilizada para um acordo internacional não é relevante e não apresenta maiores conseqüências jurídicas, haja vista que o direito internacional não faz distinção entre estes termos.

\subsection{Procedimento de Formação dos Tratados Internacionais}

Inicialmente deve-se pontuar, que as regras quanto ao exercício do poder para celebrar tratados, devem ser estabelecidas por cada Estado.

No Brasil, o processo de formação dos tratados internacionais está disciplinado na Constituição Federal de 1988. O artigo 21, inciso I, da Magna Carta, determina que compete à União manter relaçóes com Estados estrangeiros e participar de organismos internacionais. Por sua vez, o artigo 84, inciso VIII, da mesma Carta, estabelece que é da competência privativa do Presidente da República celebrar tratados, convençóes e atos

que o tratado será nulo se sua conclusão for obtida mediante ameaça ou uso da força, em violação aos princípios de Direito Internacional consagrados pela Carta da ONU”.

5 Curso de direito internacional público, p. 33.

6 Direito internacional público: curso elementar, p. 15.

7 Flávia Piovesan. Direitos humanos e o direito constitucional internacional, p. 44 
internacionais, sujeitos a referendo do Congresso Nacional. Já o artigo 49, inciso I, dispóe que é da competência exclusiva do Congresso Nacional, resolver definitivamente sobre tratados, acordos ou atos intencionais que acarretem encargos ou compromissos gravosos ao patrimônio nacional.

Assim, no procedimento de conclusão de um tratado há participação conjunta do Poder Executivo e do Poder Legislativo Federal, o Presidente da República celebra o acordo e o Congresso Nacional o aprova por intermédio de decreto legislativo (artigo 59, inciso VI, da Constituição Federal).

Alberto Xavier ensina em sua obra Direito Tributário Internacional do Brasil:

O procedimento de celebraçáo dos tratados comporta duas fases: a fase das negociaçôes e a fase da celebração. A fase das negociaçôes começa com a intervenção de agentes do Poder Executivo e termina com a autenticação, ou seja, o ato pelo qual as partes declaram concluído o processo de formação do acordo e que tem por objetivo prático fixar o texto que será submetido a ratificação. A autenticação pode revestir a modalidade de rubrica (parafatura, initialling) ou de assinatura ad referendum, por agentes munidos de Cartas de Plenos Poderes. (...) A fase da celebração inicia-se com o referendo do Congresso Nacional, o qual tem por objetivo o texto autenticado e por conteúdo autorizar o Presidente da República a ratificar o tratado. O referendo limita-se à alternativa da permissão ou rejeição da ratificação, não sendo admissível qualquer interferência no conteúdo do tratado. O referendo do Congresso Nacional reveste, assim, a natureza de uma autorização para a ratificação. A reiterada prática constitucional brasileira revela que a forma adotada para o referendo é o decreto legislativo. (...) A terceira fase do procedimento de celebração dos tratados é a fase integrativa da eficácia, que abrange a promulgação e a publicação. ${ }^{8}$

Feitas as negociaçóes, a assinatura do tratado não cria vínculo convencional, demonstra apenas a vontade do Estado signatário de assumir o vínculo. Não gera efeitos a mera assinatura do tratado se não for referendado pelo Congresso Nacional, uma vez que o Poder Executivo só realizará a ratificação depois de aprovado o tratado pelo Congresso Nacional. ${ }^{9}$ A ratificação é ato unilateral com que o sujeito de direito internacional, signatário de um tratado, exprime definitivamente, no plano internacional, sua vontade de obrigar-se. ${ }^{10}$ Trata-se de ato jurídico que gera efeitos no plano internacional.

Após a aprovação do acordo pelo Congresso Nacional, por meio do decreto legislativo e a realização da ratificação pelo Poder Executivo, há a troca ou o depósito dos

8 Direito tributário internacional do Brasil, p. 100-102.

9 Flávia Piovesan. Direitos humanos e o direito constitucional internacional, p. 49.

10 José Francisco Rezek. Direito internacional público: curso elementar, p. 53. 
instrumentos de ratificação. Por fim, a promulgação se dá por decreto do Presidente da República, trata-se de ato jurídico de natureza meramente interna, pelo qual o governo torna pública a existência de um tratado celebrado e constata o preenchimento das formalidades exigidas para a sua conclusão. ${ }^{11}$. A promulgação está sujeita a publicação no Diário Oficial, produzindo, a partir daí, efeitos no âmbito interno. ${ }^{12}$

Importante observar que, inobstante as regras contidas nos artigos 49, inciso I, e 84, inciso VIII, da Constituição Federal, não fixou a Carta Magna prazo, quer para que o Presidente da República encaminhe ao Congresso Nacional o tratado já assinado, quer para a realizaçáo do referendo pelo o Congresso Nacional ou para a ratificação pelo Chefe do Poder Executivo. Fruto desta omissão é a própria Convenção de Viena sobre o Direito dos Tratados, que foi assinada pelo Chefe do Executivo em 1969, encaminhada para referendo pelo Congresso Nacional em 1992, e está no Poder Legislativo até hoje.

\subsection{Direito Internacional e Direito Interno: Teoria Monista e Dualista}

Da discussão em torno da introdução das normas dos tratados internacionais no Direito Interno, ou seja, se após a ratificação é necessário um ato normativo interno para que o tratado passe a produzir efeitos no âmbito nacional, nasceu entre os doutrinadores o monismo e o dualismo (pluralismo).

Valério de Oliveira Mazzuoli explica a controvérsia entre as teorias: “(...) a dificuldade está em se saber se o direito internacional público e o direito interno são dois ordenamentos independentes um do outro, estanques, ou se são dois ramos de um mesmo sistema". ${ }^{13}$

Para a teoria monista o direito interno e o direito internacional formam uma única ordem jurídica e o ato de ratificação do tratado é capaz de gerar efeitos no âmbito interno e externo, havendo a incorporação automática dos tratados na ordem interna. Para a teoria dualista ${ }^{14}$ o direito interno e o internacional são ordenamentos separados e distintos, a

11 Alberto Xavier. Direito tributário internacional do Brasil, p. 102.

12 Sobre a promulgação e a publicação dos tratados, afirma José Francisco Rezek: "No Brasil se promulgam, por decreto do presidente da República, todos os tratados que tenham feito objeto de aprovação congressional. Publicam-se apenas, no Diário Oficial da União, os que hajam prescindido do assentimento parlamentar e da intervenção confirmatória do chefe do Estado. No primeiro caso, o decreto de promulgação não constitui reclamo constitucional: ele é produto de uma praxe tão antiga quanto a Independência e os primeiros exercícios convencionais do Império. Cuida-se de um decreto, unicamente porque os atos do chefe do Estado costumam ter esse nome. Por nada mais. Vale aquele ato de publicidade da existência do tratado, norma jurídica de vigência atual ou iminente. Publica-os, pois, o órgão oficial, para que o tratado - cujo texto completo vai em anexo - se introduza na ordem legal, e opere desde o momento próprio" (Direito internacional público: curso elementar, p. 84).

13 Tratados internacionais, p. 118.

14 Ressalta José Francisco Rezek: "Para os autores dualistas - dentre os quais se destacaram neste século Carl Heinrich Triepel, na Alemanha, e Dionisio Anzilotti, na Itália -, o direito internacional e o direito interno de cada Estado sâo sistemas rigorosamente independentes e distintos, de tal modo que a validade 
ratificação só gera efeitos na seara internacional, sendo imprescindível um ato normativo interno para que o tratado seja incorporado a ordem interna (incorporaçáo legislativa ou não automática) e passe a produzir efeitos. ${ }^{15}$

Kelsen, teórico monista internacionalista ${ }^{16}$, afirma em sua obra Teoria Geral do Direito e do Estado:

Essa visão monista é o resultado de uma análise das normas do Direito internacional positivo referente aos Estados, ou seja, às ordens jurídicas nacionais. A partir do ponto de vista do Direito internacional vê-se a sua conexáo com o Direito nacional e, por conseguinte, com uma ordem jurídica universal. Mas - por mais estranho que isso possa parecer - a maioria dos teóricos do Direito Internacional não compartilha essa visão monista. O direito Internacional e o Direito nacional são, na sua opinião, duas ordens jurídicas separadas, mutuamente independentes, que regulamentam matérias muito diferentes e que possuem fontes bem diferentes. ${ }^{17}$

\section{Completa Flávia Piovesan:}

A incorporação automática é adotada pela maioria dos países europeus, como a França, a Suíça e os Países-Baixos, no continente americano pelos Estados Unidos e alguns países latino-americanos, e ainda por países africanos e asiáticos. Essa forma de incorporação é amplamente considerada como a mais efetiva e avançada sistemática de assegurar a implementação aos tratados internacionais no plano interno. ${ }^{18}$

jurídica de uma norma internacional não se condiciona à sua sintonia com a ordem internacional" (Direito internacional público: curso elementar, p. 4).

15 Afirma Celso D. de Albuquerque Mello, in Teoria dos direitos fundamentais, p. 21: "A tese dualista é a mais antiga delas e já é encontrada na Constituição dos EUA, que seguiu a prática consagrada na Inglaterra. Os 'Founding Fathres' queriam evitar que o estado membro violasse o DIP. A afirmação de duas ordens jurídicas independentes, a interna e a internacional, defende a soberania do Estado". Completa ainda o autor quanto à teoria monista, p. 23: “(...) Kelsen que tanto hierarquizou as normas jurídicas já colocava várias décadas atrás que a norma fundamental era do DIP sendo regra costumeira 'pacta sunt servanda'. Esta atitude foi tomada por influência de dois internacionalistas austríacos: Josef Kunz e Alfred Verdross. O próprio Kelsen a partir da década de 30 vai se dedicar ao DIP. (...) O monismo com primado do Direito internacional vai se afirmar no século XX, principalmente após a 2a Guerra Mundial”.

16 Leciona José Francisco Rezek, in Direito internacional público: curso elementar, p. 4/5: "Os autores monistas dividiram-se em duas correntes. Uma sustenta a unicidade da ordem jurídica sob o primado do direito internacional, a que se ajustariam todas as ordens internas. Outra apregoa o primado do direito nacional de cada Estado soberano, sob cuja a ótica a adoção dos preceitos do direito internacional reponta como uma faculdade discricionária. O monismo internacionalista teve em Hans Kelsen seu expoente maior, enquanto a vertente nacionalista encontrou adeptos avulsos na França e na Alemanha, além de haver transparecido com bastante nitidez, entre os anos vinte e os anos oitenta, na obra dos autores soviéticos". Dentre os monistas nacionalistas destaca-se Wenzel.

17 Teoria geral do direito e do estado, p. 516.

18 Temas de direitos humanos, p. 70. 
Quais dentre as mencionadas teorias é a adotada pelo ordenamento jurídico brasileiro?

A doutrina predominante no Brasil entende, diante de não previsão constitucional quanto à matéria, que o Brasil adota a teoria dualista, uma vez que, se exige, para que o tratado ratificado produza efeito na ordem interna, a edição de um ato normativo, qual seja, um decreto expedido pelo Presidente da República. ${ }^{19}$

A teoria dualista, entretanto, não se aplica aos tratados internacionais de proteção dos direito humanos, ao qual aplica-se a incorporação automática, pautada pela teoria monista. Isso se dessume de regra contida na Constituição Federal, artigo 5º parágrafo $1^{\circ}$, que determina que as normas definidoras dos direitos e garantias fundamentais têm aplicação imediata, haja vista que os tratados internacionais de direitos humanos têm por objeto justamente a definição de direitos e garantias. ${ }^{20}$

No Brasil, adota-se a teoria dualista (incorporação legislativa) para todos os tratados internacionais, inclusive os que versem sobre matéria tributária, e a teoria monista (incorporação automática) para os tratados que versem sobre direitos humanos. Há, portanto, um sistema jurídico misto de incorporação das regras dos tratados internacionais no ordenamento jurídico interno.

\subsection{Hierarquia dos Tratados Internacionais na Ordem Interna}

É possível estabelecer quatro posicionamentos principais quanto à hierarquia dos tratados no ordenamento pátrio: I) a corrente que reconhece a natureza supraconstitucional dos tratados; II) a posição que atribui natureza constitucional às convençóes internacionais; III) a que reconhece patamar hierárquico das leis ordinárias; e IV) e a que reconhece caráter supralegal aos tratados.

Analisar-se á, ainda que brevemente, cada uma das correntes:

I) Natureza supraconstitucional dos tratados: tem como um dos seus defensores Celso D. Albuquerque Mello que entende que a norma internacional prevalece sobre a norma constitucional, mesmo na hipótese em que uma norma constitucional posterior tenta revogar uma norma internacional constitucionalizada. ${ }^{21}$ Essa tese é

19 Alexandre de Moraes faz distinção entre dualismo extremado e moderado: "O direito constitucional brasileiro náo exige a edição de lei formal para a incorporaçáo do ato ou tratado internacional (dualismo extremado). A incorporaçáo do ato ou tratado internacional, no âmbito do direito interno, exige primeiramente a aprovaçáo de um decreto legislativo pelo Congresso Nacional, e posteriormente a promulgaçáo do Presidente da República, via decreto, do texto convencional (dualismo moderado)" (Direito constitucional, p. 570).

20 A respeito consultar obra de Flávia Piovesan. Direitos humanos e o direito constitucional internacional, p. 80-91.

21 Teoria dos direitos humanos, p 25. 
de difícil adequação em países como no Brasil em razão da supremacia formal e material da Constituição Federal em relação a todo o ordenamento jurídico.

II) Natureza constitucional dos tratados: baseia-se no artigo $5^{\circ}$, parágrafo $2^{\circ}$, da Constituição Federal que estabelece que os direitos expressos na Constituição não excluem outros decorrentes do regime e dos princípios por ela adotados, ou dos tratados internacionais em que o Brasil seja parte. $\mathrm{O}$ citado parágrafo do artigo $5^{\circ}$ contém uma cláusula constitucional de caráter aberto na medida em que reconhece outros direitos e garantias decorrentes dos princípios e do regime adotado pela Constituição, bem como decorrentes dos tratados. ${ }^{22}$

Flávia Piovesan ${ }^{23}$ e Antônio Augusto Cançado Trindade ${ }^{24}$, como base no artigo 5º, parágrafo $1^{\circ}$ e $2^{\circ}$, da Constituição Federal defendem que a hierarquia constitucional só se aplica no caso dos tratados de direitos humanos ${ }^{25}$; os demais teriam hierarquia infraconstitucional, bem como defende a doutrinadora que em caso de conflito entre as normas do tratado e o direito interno, deve sempre prevalecer a norma mais favorável à vitima. ${ }^{26}$

Quanto aos tratados de direitos humanos, a questão da sua hierarquia no direito interno foi dirimida e pacificada, ao menos para o futuro, com a Emenda Constitucional no 45 , de 08 de dezembro de 2004, que atribuiu natureza constitucional às normas dessas convenções, ao estabelecer que os tratados de direito humanos que forem aprovados, em cada Casa do Congresso Nacional, em dois turnos, por três quintos dos votos dos respectivos membros, serão equivalentes à emendas constitucionais.

III) Natureza de lei ordinária dos tratados: para essa corrente os tratados internacionais ingressam no ordenamento jurídico nacional com status de lei ordinária, de modo que, em caso de conflito aplica-se o princípio "lei posterior revoga a anterior que seja com ela incompatível”. Preconiza a paridade dos tratados internacionais com as leis internas. ${ }^{27}$

Esse posicionamento foi adotado pelo Supremo Tribunal Federal em 1977 quando do julgamento do Recurso Extraordinário no 80.004/SE, em 1o de junho de 1977,

22 José Afonso da Silva. Curso de direito constitucional positivo, 191.

23 Direitos humanos e o direito constitucional internacional, p. 52.

24 Antônio Augusto Cançado Trindade. A proteção internacional dos direitos, p. 631 apud Flávia Piovesan. Direitos humanos e o direito constitucional internacional, p. 53.

25 Vide posição do Ministro Carlos Velloso no julgamento do HC no 82.424/RS

26 Direitos humanos e o direito constitucional internacional, p. 64.

27 Leciona Flávia Piovesan: "Insiste-se que a teoria da paridade entre o tratado internacional e a legislação federal náo se aplica aos tratados de direitos humanos, tendo em vista que a Constituiçáo de 1988 assegura a estes garantia de privilégio hierárquico, atribuindo-lhe natureza de norma constitucional. ... justifica-se na medida em que os tratados internacionais de direitos humanos apresentam um caráter especial, distinguindo-se dos tratados internacionais comuns" (Direitos humanos e o direito constitucional internacional, p. 65). 
posição que foi confirmada mesmo após o advento da Constituição Federal de 1988, com o julgamento do Habeas Corpus no 72.131/RJ, em 22 de novembro de 1995. Posteriormente, no julgamento da medida cautelar na ADI no 1.480-3/DF, em 04 de setembro de 1997, voltou o tribunal a afirmar a paridade do tratado internacional com as leis internas, ordinárias e não as complementares, tese que se mantém nos julgamentos do tribunal superior. ${ }^{28}$ Entretanto, diante do voto do relator Cezar Peluso no RE no 466.343-1/SP, voto que foi acompanhado por outros Ministros, tudo indica que essa posiçáo do Supremo Tribunal Federal será revisada ${ }^{29}$, ao menos, no que tange aos tratados de direitos humanos.

Essa concepção compromete não só o princípio da boa-fé pelo qual compete ao Estado cumprir às disposiçôes do tratado, com o qual consentiu livremente, como também a Convenção de Viena sobre o Direito dos Tratados que no artigo 27 determina náo poder o Estado invocar disposiçóes de direito interno como justificativa para o náo cumprimento de tratado. Além de demonstrar a indiferença do Estado em relação às conseqüências da não observância do plano internacional, já que autoriza o Estado signatário a violar normas da ordem internacional.

IV) Natureza supralegal, porém infraconstitucional: essa tese é defendida com base no artigo 102, inciso III, alínea "b", da Constituição Federal que atribui ao Supremo Tribunal Federal a competência para julgar, mediante recurso extraordinário, in verbis:

"as causas decididas em única ou em última instância, quando a decisão recorrida declarar a inconstitucionalidade de tratado ou lei federal".

Reforça essa corrente o mencionado princípio da boa-fé, vigente no direito internacional, haja vista que, a Convençáo de Viena, determina que o Estado não pode invocar seu direito interno como justificativa para o náo-cumprimento de tratado.

Esta tese foi abarcada pelo voto do Ministro Relator Cézar Peluso no recente julgamento do RE no 466.433-1/SP, cujo plenário foi realizado em 22 de novembro de 2006, e foi acompanhada por outros Ministros, ao entenderem que os tratados de direitos humanos (anteriores à EC no 45 e que não tenham observado o quórum do artigo $5^{\circ}, \$ 3^{\circ}$, da CF) tem hierarquia supralegal e não legal.

$28 \mathrm{HC} \mathrm{n}^{\circ}$ 79.870/SP, Rel. Min. Moreira Alves, DJ 20.10.2000; RE no 206.482/SP, Rel. Min. Maurício Corrêa, DJ 5.9.2003 e HC no 81.139/GO, Rel. Min. Celso de Mello, DJ 19.8.2005.

29 RE no 466.343-1/SP: Após o voto Ministro Cezar Peluso (Relator), que negava provimento ao recurso, no que foi acompanhado pelo Ministro Gilmar Mendes, pela Ministra Cármen Lúcia e pelos Ministros Ricardo Lewandowski, Joaquim Barbosa, Carlos Britto e Marco Aurélio, pediu vista dos autos o Senhor Ministro Celso de Mello. Ausentes, justificadamente, os Ministros Sepúlveda Pertence e Eros Grau. Presidência da Ministra Ellen Gracie. Plenário, 22.11.2006. Vide voto do Ministro relator que entendeu que os tratados de direitos humanos tem hierarquia supralegal e não legal: http://www.stf. gov.br/imprensa/pdf/re466343.pdf. 
Referida posição já foi adota outrora pelo Supremo Tribunal Federal, a título de exemplo é possível citar os julgados preferidos na Apelação Civil no 9.587, de 1951 e na Apelação Cível no 7.872, de 1943.

Diante dos quatro posicionamentos, a tese adotada pelo trabalho é a da existência de um sistema misto disciplinador dos tratados, um regime a ser aplicado aos tratados de direitos humanos e outro aos demais tratados, inclusive aos de matéria tributária.

Assim, os tratados de direitos humanos que tenham observado o quórum exigido pelo artigo $5^{\circ}$, parágrafo $3^{\circ}$, da Constituição Federal são recebidos pelo ordenamento jurídico nacional como equivalentes às emendas constitucionais, têm, portanto, hierarquia constitucional. Já os tratados de direito tributário, os de direitos humanos que não tenham observado o quórum e os demais, são recebidos como normas supralegais, tem hierarquia superior às normas internas, porém, inferior às normas constitucionais.

\section{Tratados Internacionais como Fonte do Direito Tributário}

Dentro das fontes internacionais do direito tributário os tratados ocupam lugar de primordial relevo.

Nas palavras de Luciano Amaro: "Os tratados internacionais têm, modernamente, uma grande atuação no campo dos tributos, ao estabelecerem mecanismos que evitam a dupla tributação internacional de rendimentos e reduzem ou excluem ônus tributários no comércio internacional" ${ }^{30}$

Alberto Xavier leciona que os tratados em matéria tributária são, via de regra, bilaterais, uma vez que os coletivos ocupam no direito tributário internacional um lugar secundário. ${ }^{31-32}$

A palavra fonte significa origem, causa, a nascente de água ${ }^{33}$. Assim como a água brota da fonte o direito tributário também tem suas fontes.

30 Direito tributário brasileiro, p. 178.

31 Direito tributário internacional do Brasil, p. 92.

32 Afirma Aliomar Baleeiro: "Em regra, os tratados só produzem efeitos entre as partes que os celebram. Mas, além da hipótese de adesão, os tratados de comércio com concessōes alfandegárias, contêm, em geral, há alguns séculos, a 'cláusula de nação mais favorecida'. Por ela, esses atos internacionais consignam que se maiores concessōes, no futuro, forem feitas a um terceiro país, elas se tornarăo extensivas automaticamente aos signatários. Se, p. ex., Brasil e Argentina estipulam que as importaçóes de frutas frescas dum para outro gozarăo da redução de $50 \%$ dos direitos aduaneiros e, mais tarde, um desses países concede $75 \%$ de redução a uma terceira nação, relativamente à mesma mercadoria, assim mais favorecida, essa vantagem automaticamente será assegurada ao outro contratante" (Direito tributário brasileiro, p. 639)

33 Dicionário larousse escolar da língua portuguesa, p. 351. 
A doutrina distingue as fontes do direito tributário em: fontes formais e fontes materiais. $^{34}$

As fontes materiais ou reais são os pressupostos fáticos da tributação, ou seja, o pressuposto de fato que compóe a hipótese de incidência tributária. É, como dispóe o artigo 114 do Código Tributário Nacional: "A situação definida em lei como necessária e suficiente a sua ocorrência”. Trata-se de um fato, descrito em uma norma geral e abstrata, que, uma vez ocorrido no mundo concreto opera o fenômeno da subsunção tributária (amoldamento perfeito do fato à norma).

Fontes formais são os conjuntos de normas que dão origem ao direito tributário. São simbolizadas pelo plexo de normas pelo qual o direito se instrumentaliza, ganhando força obrigatória e vinculante e criando direitos e deveres jurídicos.

Proposta sumariamente uma classificação das fontes do direito tributário, os tratados internacionais devem ser catalogados como fontes formais, ao lado dos atos normativos previstos no artigo 59 da Constituição Federal e dos decretos.

\subsection{Conceito da Expressão "Legislação Tributária"}

O Código Tributário Nacional (Lei no 5.172/66) define o termo "legislação tributária” em seu artigo 96, ao estabelecer que esta expressão compreende as leis, os tratados e as convençóes internacionais, os decretos e as normas complementares ${ }^{35}$ que versem, no todo ou em parte, sobre tributos e relaçóes jurídicas a eles pertinentes. ${ }^{36}$

Adotou o diploma tributário um conceito amplo de legislação tributária, de modo que, lei e legislação tributária são termos que não se confundem, já que a expressão não se limita aos atos formalmente considerados como lei.

34 Kiyoshi Harada. Direito financeiro e tributário, p. 315. Essa classificação também é encontrada em Eduardo Marcial Ferreira Jardim. Manual de Direito Financeiro e Tributário. p. 139.

35 Artigo 100 do CTN: "Sáo normas complementares das leis, dos tratados e das convençóes internacionais e dos decretos: I - os atos normativos expedidos pelas autoridades administrativas; II - as decisões dos órgãos singulares ou coletivos de jurisdição administrativa, a que a lei atribua eficácia normativa; III - as práticas reiteradamente observadas pelas autoridades administrativas; e IV - os convênios que entre si celebram a União, os Estados, o Distrito Federal e os Municípios".

36 Paulo de Barros Carvalho, Curso de direito tributário, p. 93-94, faz críticas ao artigo ao mencionar: "Em homenagem ao mínimo de rigor e coerência que o sistema deve apresentar, não nos parece correta a formulaçấo esquematizada nesse Estatuto. Tirando as leis, os decretos e, entre as normas complementares, os atos normativos expedidos pelas autoridades administrativas e as decisóes dos órgáos singulares ou coletivos de jurisdição administrativa a que a lei atribui eficácia normativa (art. 100, I e II), que são instrumentos introdutórios primários ou secundários, no ordenamento positivo brasileiro, todos os outros, tratados e convençôes internacionais, bem como as práticas reiteradamente observadas pelas autoridades administrativas e os convênios que entre si celebram a União, os Estados, o Distrito Federal e os Municípios, esses últimos na qualidade de normas complementares, são vazios de força jurídica vinculante, não integrando o complexo normativo. ... não são os tratados e as convençôes internacionais que têm idoneidade jurídica para revogar ou modificar a legislação interna, e sim os decretos legislativos que o ratificam, incorporando-os à ordem jurídica”. 
O artigo 96 do Código Tributário Nacional não tem o condão de restringir o conceito de legislação tributária, mas, ao contrário, pretende demonstrar a sua amplitude em relação ao conceito de lei tributária. ${ }^{37}$

Inobstante tenha o Código feito referência aos tratados e as convençóes internacionais como se fossem termos distintos, como foi demonstrado no trabalho, os conceitos de tratado e convenção internacional são sinônimos.

Ao estabelecer que os tratados estão contidos na expressão legislação tributária, reconhece expressamente o legislador que as convençôes internacionais são fontes do direito tributário.

Como demonstrado, os tratados ingressam no ordenamento jurídico nacional por intermédio de um ato normativo nacional, qual seja, o decreto de execuçáo, antecedido do decreto legislativo, e se o Código mencionou que a expressão legislação tributária compreende, distintamente, as lei (dentre elas o decreto legislativo), os tratados e as convençóes internacionais e os decretos, é porque reconhece que os tratados internacionais no ordenamento pátrio tem uma posição hierárquica que lhes são próprios.

\subsection{A Regra do Artigo 98 do Código Tributário Nacional}

Estabelece o artigo 98 do Código Tributário Nacional, in verbis:

Os tratados e as convençóes internacionais revogam ou modificam a legislação interna, e serão observados pela que lhes sobrevenha.

O diploma tributário reconhece, expressamente neste artigo, a supremacia dos tratados internacionais sobre a legislação interna ${ }^{38}$, certifica que são supralegais, entretanto, trás grave impropriedade terminológica.

É incorreta a redação do preceito quando se refere a revogação ou modificação da lei interna pelos tratados. O que ocorre, não é a revogação ou a modificação da legislação interna por uma convenção internacional, mas sim há limitação da eficácia da lei interna que se torna inaplicável aos casos regulados pelos tratados internacionais. ${ }^{39}$

37 Leciona Hugo de Brito Machado: "No Código Tributário Nacional, a palavra lei é utilizada em seu sentido restrito, significando regra jurídica de caráter geral e abstrato, emanada do Poder ao qual a Constituição atribui competência legislativa, com observância das regras constitucionais pertinentes à elaboração das leis. Só é lei, portanto, no sentido em que a palavra é empregada no CTN, a norma jurídica elaborada pelo Poder competente para legislar, nos termos da Constituição, observado o processo nesta estabelecido" (Curso de direito tributário, p. 87-88).

38 Decisōes neste sentido: RE no 99.376/RS. Rel. Min. Moreira Alves, julgamento 1.6.1984 e RE no 90.824/SP Rel. Min. Moreira Alves. DJ 19.9.80.

39 Afirma Luciano Amaro que: "Por isso, como assinalamos linhas acima, a eventual denúncia do tratado (afastando o preceito especial ou de exceção nele estabelecido) implica voltarem aqueles casos a submeter- 
Mesmo para os que defendem a paridade entre o tratado e a lei ordinária, que não é a tese defendida neste trabalho, a aplicação prevalente do tratado resultará de uma relaçáo de especialidade.

\section{Afirma Luciano Amaro ${ }^{40}$ :}

“..., nada mais é do que aplicar os preceitos convencionais (do tratado) em harmonia (e não em confronto) com a legislação interna. Nesse plano, não se pôe, tecnicamente, a questão de o tratado "revogar" ou não a lei interna. Cuida-se de normas especiais que, anteriores ou posteriores à lei geral (lei interna), com ela convivem. Na situaçáo especial (qualificada no tratado), ou a lei interna não se aplica (porque o tratado afasta - na hipótese - sua incidência), ou a lei interna é aplicável com a limitação prevista no tratado". ${ }^{41}$

Os tratados e as convençóes internacionais prevalecem sobre a legislação interna, seja anterior ou posterior. Nesse sentido, leciona Hugo de Brito Machado:

$\mathrm{Na}$ verdade um tratado internacional não revoga nem modifica a legislação interna. A lei revogada não volta a ter sua vigência pela revogação da lei que a revogou. Denunciado um tratado, todavia, a lei interna com ela incompatível estará restabelecida, em pleno vigor. Tem-se que procurar, assim, o significado da regra legal em foco. O que ela pretende dizer é que os tratados e convençóes internacionais prevalecem sobre a legislação interna, seja anterior ou mesmo posterior. ${ }^{42}$

Por outro lado, face à superioridade hierárquica, os tratados internacionais não podem ser revogados ou modificados por leis internas. Os tratado internacionais devem ser

se à aplicação da lei interna anterior ao tratado (com as modificaçóes que ela eventualmente tenha sofrido mercê de outras leis internas). Não se dá aí represtinação; o que ocorre é que perde eficácia a norma especial que afastava da disciplina da norma geral determinada hipótese, fazendo com que esta volte a submeter-se à norma geral. Em suma, em vez de revogar a lei interna, o tratado cria (nas situaçóes por ele previstas e em relação aos países com os quais foi firmado) exceções à aplicação da lei interna, cuja revogação (das exceçóes) restabelece a lei interna”. (Direito tributário brasileiro, p. 180. Ver também Alberto Xavier. Direito Tributário Internacional do Brasil. p.124 e Vladimir Passos de Freitas (Coord.). Código tributário nacional comentado. p. 502.

40 Nesse sentido Aliomar Baleeiro. Direito tributário brasileiro. p. 640-643.

41 Curso de direito tributário brasileiro. p. 179. Completa o autor: "É obvio que o tratado, nessas circunstâncias, não revoga, nem totalmente (ab-rogação) nem parcialmente (por derrogação), a lei interna. Tanto que, em relação aos demais países, nâo signatários do tratado, a lei interna brasileira continua sendo aplicada na sua inteireza; a lei interna permanece em vigor para aplicação, mesmo em relação aos países signatários do tratado, às situaçóes neste não previstas. Nas hipóteses reguladas no tratado, quando este fixe o limite até o qual cada país signatário pode tributar, a norma de incidência tributária que efetivamente se aplica também é a lei interna, sem a qual, mesmo autorizada pelo tratado a cobrança do tributo até tal ou qual limite, nada se poderia cobrar”.

42 Curso de direito tributário. p. 94. 
respeitados pelo Congresso Nacional, que os referenda, e somente devem ser alterados pela via apropriada.

Em razão da natureza supralegal, porém infraconstitucional dos tratados, não podem as avenças internacionais contrariar a Constituição Federal, conforme será demonstrado.

Em que pese a defesa da inconstitucionalidade do artigo 98 do Código Tributário Nacional por renomados tributaristas ${ }^{43}$, o dispositivo legal foi recepcionado pelos artigos $4^{\circ}$, inciso IX, e seu parágrafo único, bem como pelo artigo $5^{\circ}$, parágrafo $2^{\circ}$, todos da Constituição Federal, sendo, portanto, constitucional.

Há ainda os que defendem ${ }^{44}$ a regularidade técnica do artigo 98 do Código Tributário Nacional, afirmando que os tratados internacionais podem revogar ou modificar a legislação interna.

\subsection{Hierarquia dos Tratados Internacionais de Direito Tributário na Ordem Interna}

Existem quatro posicionamentos principais quanto à hierarquia dos tratados no ordenamento pátrio: I) a corrente que reconhece a natureza supraconstitucional dos tratados; II) a posição que atribui natureza constitucional às convenções internacionais; III) a que reconhece patamar hierárquico das leis ordinárias; e IV) e a que atribui caráter supralegal aos tratados.

Atualmente, a Constituição Federal estabelece, nos termos do artigo $5^{\circ}$, parágrafo $3^{\circ}$, da Constituição Federal, a natureza constitucional dos tratados de direitos humanos, aprovados com o quórum no dispositivo exigido, já que são equivalentes às emendas constitucionais.

Os demais tratados têm hierarquia infraconstitucional. Afirma Flávia Piovesan:

43 Dentre os defensores da inconstitucionalidade encontra-se Roque Antonio Carrazza que afirma: "Particularmente inaceitável, ao lume de nossa Constituição, a idéia de que os tratados `revogam ou modificam a legislação tributária interna, e serão observados pela que lhes sobrevenhà. É certo que os tratados internacionais, uma vez em vigor no País, incorporam-se ao Direito interno brasileiro. Não é menos certo, porém, que, quando isto acontece, alojam-se no mesmo patamar hierárquico das leis lato sensu (leis complementares, leis ordinárias, leis delegadas, medidas provisórias e resoluçóes), podendo, deste modo, ser revogados ou modificados "pela legislaçáo interna (...) que lhes sobrevenha". (Curso de direito constitucional tributário, p 246). Agostinho Toffoli Tavolaro, in Curso de direito tributário, p. 398, leciona: "Tem-se verberado a inconstitucionalidade do art. 98, principalmente após a Constituição de 1988, argüindo-se: a) o princípio les posteriori derogat anteriori; b) a falta de embasamento constitucional do dispositivo, pois náo constituiria em matéria de lei complementar; e c) porque ocasionaria o ferimento do princípio federativo, interferindo na autonomia dos poderes impositivos dos Estados e dos Municípios".

44 Vide Kiyoshi Harada. Direito financeiro e tributário. p. 467 e Paulo de Barros Carvalho. Curso de direito tributário. p. 79. 
Há que enfatizar ainda que, enquanto os demais tratados internacionais tem força hierárquica infraconstitucional, os direitos enunciados em tratados internacionais de proteção dos direitos humanos apresenta valor de norma constitucional. (...) Sustenta-se assim, que os tratados tradicionais têm hierarquia infraconstitucional, mas supralegal. ${ }^{45}$

Em que posição em sentido contrário ${ }^{46}$, possui natureza infraconstitucional não só os demais tratados, como também os tratados de direitos humanos que não forem aprovados com o quórum exigido pela Emenda Constitucional no 45/04.

Os tratados internacionais de direito tributário têm, portanto, hierarquia infraconstitucional, porém são supralegais.

Diante da norma do artigo 98 do Código Tributário Nacional, há que se reconhecer que os tratados de direito tributário são normas de hierarquia superior às leis internas do país. ${ }^{47}$ As convençóes internacionais devem prevalecer sobre as normas internas porque são atos do Estado brasileiro, que não podem ser desconsiderados pelas pessoas jurídicas de Direito Público interno. ${ }^{48}$

As normas dos tratados internacionais não podem contrariar as regras constitucionais, haja vista que estão abaixo destas. ${ }^{49}$ Leciona Roque Antonio Carrazza: "Realmente é inadmissível a prevalência de tratado internacional contra o texto expresso da Constituição ou, o que é mais grave, contra os princípios que ela incorpora" ${ }^{50}$

Caso o tratado internacional seja firmado contra norma constitucional ou se a inconstitucionalidade for superveniente, Kiyoshi Harada oferece solução:

Essas normas internacionais só estão abaixo das normas constitucionais. Se o Tratado for firmado contra expresso texto constitucional, o Congresso Nacional poderá deixar de ratificá-lo e, se ratificado, poderá ter a sua inconstitucionalidade declarada pelo STF. Entretanto, se a inconstitucionalidade for superveniente, resultando, por exemplo, de uma emenda constitucional, o Tratado não poderá ser simplesmente ignorado sob a alegação de que houve derrogação. No exercício de sua soberania (art. $1^{\mathrm{o}}$, I, e $4^{\mathrm{o}} \mathrm{da} \mathrm{CF}$ ) o conflito de normas deve ser resolvido de acordo com os princípios que regem o direito das gentes. $\mathrm{O}$ tratado deve ser denunciado. ${ }^{51}$

45 Direitos humanos e o direito constitucional internacional. p. 59.

46 Flávia Piovesan. Direitos humanos e o direito constitucional internacional. p. 72-73.

47 "A conclusáo de que os tratados têm supremacia hierárquica sobre a lei interna e se encontram numa relação de especialidade em relação a esta, é confirmada em matéria tributária, pelo artigo 98 do Código Tributário Nacional..." (Alberto Xavier. Direito tributário internacional do Brasil, p. 123).

48 Hugo de Brito Machado. Tributação no mercosul, p. 91.

49 O STF adotou essa tese no julgamento do $\mathrm{HC} \mathrm{n}^{\circ}$ 75.306-0-RJ.

50 Curso de direito constitucional tributário, p 203.

51 Kiyoshi Harada. Tributação no mercosul, p. 208-209. 
As normas internacionais de direito tributário tem patamar hierárquico superior ao da legislação interna, são supralegais, mas infraconstitucionais. Caso as convençôes internacionais contenham normas que contrariam a Constituição Federal, compete ao Congresso Nacional não ratificá-lo. $\mathrm{Na}$ hipótese de ratificação, a inconstitucionalidade deverá ser declarada pelo Superior Tribunal de Justiça. Advindo emenda constitucional contrária às regras do tratado, o conflito deverá ser resolvido através da denúncia ${ }^{52}$ do acordo internacional.

\section{Conclusões}

Os tratados internacionais são hoje a principal fonte de obrigaçóes no âmbito internacional.

Não é relevante, nem apresenta maiores conseqüências jurídicas, a denominação adotada, dentre as várias existentes, para o termo "tratado". O processo de elaboração dos tratados, no Brasil, constitui-se por um ato jurídico complexo, envolvendo a manifestação conjunta do Presidente da República (celebração, ratificação e promulgação) e do Congresso Nacional (referendo por meio do decreto legislativo). Existem duas teorias que tratam do processo de incorporação do direito internacional ao direito interno, quais sejam, teoria monista e dualista.

O Brasil adota um sistema misto de incorporação dos tratados internacionais. Aplica-se a teoria dualista (incorporação legislativa) para todos os tratados internacionais, inclusive para os que versem sobre matéria tributária, exceto para os tratados de direitos humanos, em relação aos quais adota-se a teoria monista (incorporação automática). Há quatro correntes em relação à hierarquia dos tratados no ordenamento pátrio: I) a posição que reconhece a natureza supraconstitucional; II) a corrente que atribui natureza constitucional; III) a que vislumbra patamar hierárquico das leis ordinárias; e IV) e a que atribui caráter supralegal, mas infraconstitucional. Mais uma vez, o ordenamento jurídico nacional adota um sistema misto.

Os tratados internacionais de direitos humanos que forem aprovados nos termos do artigo $5^{\circ}$, parágrafo $3^{\circ}$ da Constituição Federal, tem natureza de norma constitucional. Aos tratados de direitos humanos tem aplicação, portanto, a segunda corrente. Já os tratados de direitos humanos não aprovados nos termos do artigo $5^{\circ}$, parágrafo $3^{\circ}$, da Constituição Federal, os tratados de direito tributário e as convenções que versem sobre qualquer matéria, tem status hierárquico infraconstitucional, mas supralegal. Para estes tratados tem aplicação a quarta corrente.

52 Ato unilateral pelo qual o Estado manifesta a vontade de não mais fazer parte do tratado. 
Os tratados internacionais têm grande atuação na seara tributária porque evitam a dupla tributação e diminuem encargos tributários no comércio internacional. São fontes formais do direito tributário, o que o legislador reconhece expressamente no artigo 96 do Código Tributário Nacional, dispositivo este que define a expressão "legislação tributária”. O artigo 98 do mesmo Código reconhece expressamente a supremacia do tratado internacional sobre a legislação interna, entretanto, contém impropriedade terminológica ao determinar que os tratados e as convençôes internacionais revogam ou modificam a legislação interna, e serão observadas pela que lhes sobrevenha. É que os tratados internacionais não revogam, nem modificam a legislação interna, apenas limitam a eficácia da lei interna com eles incompatível. Em relação aos países não signatários do tratado a lei interna continua tendo eficácia e aplicabilidade e, caso o tratado seja denunciado, a norma interna volta a ter aplicabilidade, já que sua eficácia retorna.

Os tratados internacionais de direito tributário tem hierarquia supralegal na ordem interna, porém infraconstituicional. Estão acima da legislação interna, seja anterior ou posterior, e estão abaixo da Constituição Federal, de modo que, os tratados com ela incompatíveis não deverão ser referendados pelo Congresso Nacional e, caso sejam, serão passíveis de declaração de inconstitucionalidade pelo o Supremo Tribunal Federal. Na hipótese de inconstitucionalidade superveniente à celebração do tratado, deverá o mesmo ser denunciado.

\section{Referências}

AMARO, Luciano. Direito tributário brasileiro. 20. ed. rev. e atual. São Paulo: Saraiva, 2014.

ARAÚJO, Luís Ivani de Amorim. Curso de direito internacional público. 9a ed. Rio de Janeiro: Forense, 1998.

BALEEIRO, Aliomar. Direito tributário brasileiro. 11 ed. Rio de Janeiro: Forense, 2003.

CARRAZZA, Roque Antonio. Curso de direito constitucional tributário. 26. ed. rev., amp. e atual. até Emenda Constitucional n 64/2010. São Paulo: Malheiros, 2010.

CARVALHO, Paulo de Barros. Curso de direito tributário. 26. ed. São Paulo: Saraiva, 2014.

FREITAS, Vladimir Passos de (Coord.). Código tributário nacional comentado. 3. ed. rev., atual. e amp. São Paulo: Editora Revista dos Tribunais, 2005.

HARADA, Kiyoshi. Direito financeiro e tributário. 23. ed. rev. e amp. São Paulo: Atlas, 2014.

JARDIM, Eduardo Marcial Ferreira. Manual de direito financeiro e tributário. 7. ed. rev. e atual. São Paulo: Saraiva, 2005. 
JO, Hee Moon. Introdução ao direto internacional. São Paulo: LTr, 2000.

KELSEN, Hans. Teoria geral do direito e do estado. 4a . ed. São Paulo: Martins Fontes, 2005.

MACHADO, Hugo de Brito. Curso de direito tributário. 34. ed. rev., atual. e amp. São Paulo: Malheiros, 2013.

MARTINS. Ives Gandra da Silva (Coord.). Curso de direito tributário. 8a ed. São Paulo: Saraiva, 2001.

. Tributação no mercosul. 2a ed. atual. São Paulo: Revista dos Tribunais, 2002.

MAZZUOLI, Valério de Oliveira. Tratados internacionais. São Paulo: Juarez de Oliveira, 2001.

MELLO, Celso D. de Albuquerque. O Parágrafo $2^{\circ}$ do art. $5^{\circ}$ da Constituição Federal. In: TORRES, Ricardo Lobo (org.). Teoria dos direitos fundamentais. 2 ed. Rio de Janeiro: Renovar, 2009.

MORAES. Alexandre de. Direito Constitucional. 30 ed. São Paulo: Atlas, 2014.

PIOVESAN, Flávia. Temas de direitos humanos. 5 ed. São Paulo: Saraiva, 2012.

. Direitos humanos e o direito constitucional internacional. $7^{\text {a }}$ ed., amp. e atual. São Paulo: Saraiva, 2006.

REZEK, José Francisco. Direito internacional público: curso elementar. 14 ed. rev. São Paulo: Saraiva, 2013.

RODRIGUES. Diego (Coord.). Dicionário larousse escolar da língua portuguesa. São Paulo: Larousse do Brasil, 2004.

SILVA, José Afonso da. Curso de direito constitucional positivo. 38 ed. rev. São Paulo: Malheiros, 2015.

Supremo Tribunal Federal: http://www.stf.gov.br/imprensa/pdf/re466343.pdf. Acesso em: 10 de março de 2015.

TORRES, Ricardo Lobo. Curso de direito financeiro e tributário. 19. ed. rev. atual. Rio de Janeiro: Renovar, 2013. 